\title{
The Importance of Macro Practice Emphasis in Social Work Education
}

\author{
Nafees Alam* \\ Researcher, Yeshiva University, USA
}

Submission: August 08, 2019; Published: August 21, 2019

*Corresponding author: Nafees Alam, Professor, Researcher, Yeshiva University, USA

\section{Abstract}

Social work education programs across the United States continue to contend with the economic pressures of developing curricula that are financially viable in a highly competitive academic market. Fund allocation to create and develop macro programs depends on funders and donors having a close and consistent association with the institution's environment, processes and practices. Marketing is at the forefront of organizational and institutional success. Thus, recruiting and graduating students specifically for and from the macro concentration would make for mutually beneficial relationships between students looking to maximize their career potential and programs looking to maximize their enrollment and outreach.

Keywords: Social Work Education; Macro Practice; Organizational Management; Leadership

\section{Statement of the Issue}

An essential facet to health and human service organizations (HHSOs) successfully addressing the challenges facing many disenfranchised communities today are organizational leaders and managers of the social work profession, trained in macro practice [1]. Despite this understanding, few professionals with backgrounds in social work occupy such positions of leadership within HHSOs, resulting in a significant deficit in the unique values and perspectives brought forth by such experiences [2]. Social work education plays an integral role in preparing students with values of social justice and ethical-professional acumen to compete for leadership positions within HHSOs. The Rothman [2] Report provides a well-documented assessment of the deterrents to schools of social work establishing and sustaining macro practice concentrations (e.g. limited financial investment).

\section{History \& Current Position of Macro Social Work}

\section{History of macro practice in academia \& organizations}

Macro practice interventions utilize a neighborhood and community focus, employing practice interventions in the areas of locality development, social planning and social advocacy [3]. According to the Council on Social Work Education (CSWE), it wasn't until 1962 that social work accredited community organization as a legitimate practice method equivalent to casework. Meaning, the age of macro practice is about half of that of clinical practice. Consider for a moment that the profession of social justice and ethical-professional acumen did not acknowledge the legitimacy of mass public empowerment for half-a-century, still today placing greater value in working with individuals and families over communities and jurisdictions. The need for the latter gaining traction and finding platform remains omnipresent [4].

However, the advance of macro practice cannot come at the regression of clinical practice. Clinicians employ a myriad of techniques working with clients and it is important to acknowledge that individuals are, in many ways, products of their environment and society. Thus, clinical practitioners must strive to incorporate macro concepts into practice just as macro practitioners must strive to do the same with clinical concepts [5]. In order to best serve the society, collaboration between clinical and macro social workers with the target community is strategically sound in defining problems and discovering solutions. This approach has the added benefit of empowering individuals, as well as community-based organizations, to use evaluation data to make decisions on their own behalf [6].

The International Federation of Social Workers' policy paper states: 'social work has always been a human rights profession, the basic principle is the value of every human being and the promotion of equitable social structures, which offers people security while protecting their dignity' ("IFSW," 1988). The time has come to begin giving equal credibility and legitimacy to these macro-level 'social structures [7]. 


\section{Current role of macro practice in academia \& organizations}

It is imperative that organizations implement a strategic plan with measurable goals. The process of strategic planning is longlasting, systematic and community based, integrating short and long-term goals, allowing for organizations to build innovative programs for clients [8]. Macro-track social work students learn the necessary skills to implement strategic plans as part of their curriculum. For most non-macro-track students, there remains a disconnect between the importance of macro-practice concepts needed in organizational development and the lack of emphasis on macro-practice concepts in their curriculum.

According to MSWcareer.com, as of 2011, only 8.8\% of social work students choose a concentration in macro practice. In fact, many schools fail to offer macro courses and there is an overall absence of a macro concentration. An historically consistent trend, focusing on clinical social work in academia, leading to the marginalization of macro practice. Some social work department administrators simply do not value a macro curriculum, nor provide adequate resources and financial allocation for it. Such practices range from uncooperative, disruptive attitudes of clinical colleagues to the lack of access to resources, in addition to minimal recruitment and employment of macro faculty [9].

Social work education, particularly evidence-based practice, has been about the integration of theory and practice, though most commonly employed in work with individuals, families and groups. When students are exposed to the rich experience of empowerment brought on by social change and social reform, they acknowledge the relevance and impact of social work at the macro level [10]. There remains a clear gap between clinical and macrotrack social work education. Experiential learning, commonly thought to be of greatest value throughout social work education, remains lacking regarding macro practice. Within social work organizations, the transfer of knowledge is macro-level work. Evidence indicates that organizations that transfer knowledge effectively from one department or organization to another are far more productive and more likely to be successful [11].

\section{Economic \& Socioeconomic Strategies for Survival}

There are currently no government or nonprofit platforms where wide-scale social work salaries are publicly disclosed. Glassdoor.com, a database where people submit information about their organization, role, salary, benefits and more, shows the national average annual salary for a director of social services in the United States is $\$ 92,358$, while the national average salary for a clinical social worker is $\$ 51,737$. In the state of New York, social workers with a graduate degree in a clinical concentration are eligible to take the Licensed Master of Social Work (LMSW) exam in addition to the Licensed Clinical of Social Work (LCSW) exam, whereas their macro concentration colleagues are only eligible to take the LMSW exam. Although literature suggests that a macro-specific license would provide greater accountability and a standardized level of professionalism and competency [12], there is currently no specific license designated for macro practitioners. This means that despite being eligible to take one more exam, adding to their resumes and curriculum vitae and seemingly being more qualified, clinical practitioners still earn $\$ 40,621$ less annually than macro practitioners who may themselves have lesser credentials.

Social work education programs across the United States continue to contend with the economic pressures of developing curricula that are financially viable in a highly competitive academic market [13]. Fund allocation to create and develop macro programs depends on funders and donors having a close and consistent association with the institution's environment, processes and practices. Marketing is at the forefront of organizational and institutional success. Thus, recruiting and graduating students specifically for and from the macro concentration would make for mutually beneficial relationships between students looking to maximize their career potential and programs looking to maximize their enrollment and outreach.

\section{Recommendations}

The engagement of social work faculty in discussions pertaining to the value of macro social work and how it fits in with direct practice could begin the process of stakeholder buy-in. The more social work faculty value macro practice, the more likely they are to effectively communicate their ideas with students, potentially sparking a greater level of interest in macro social work.

The marketing and recruitment of clinical students into schools of social work nationwide have been successful, suggesting the potential for improvement in the marketing and recruitment of macro students. An equal level of effort in attracting clinical and macro students could make for greater equality in representation between clinical and macro students.

Funding is integral to the growth and success of any initiative. Increasing the allocation of funds toward macro practice, in conjunction with faculty engagement and student marketing and recruitment, could be the best opportunity for macro practice in social work education to gain ground on clinical practice, thereby strengthening the overall social work curriculum and profession.

\section{References}

1. Mott A (2008) Community Learning Project Report on University Education for Social Change. ( $2^{\text {nd }}$ edn), USA.

2. Rothman J (2013) Education for Macro Intervention: A survey of Problems and Prospects. Lynwood, IL: Association for Community Organization and Social Administration. USA.

3. Rothman J (1995) Strategies of community intervention: Macro practice. Business and Economics 5: 27-64.

4. (1962) Curriculum policy statement.

5. Payne M (2016) Modern social work theory. ( $4^{\text {th }}$ edn), Oxford, NY: Oxford University Press. USA. 
6. Ohmer ML (2008) Assessing and Developing the Evidence base of Macro Practice: Interventions with a Community and Neighborhood Focus. Journal of Evidence-Based Social Work 5(3-4): 519-547.

7. (1988) International federations of social workers.

8. Perera R, DePaula F, Manel P (2012) Strategic Planning in Healthcare Organizations. Organizations and Administration 65(8): 749-754.

9. Rothman J Mizrahi T (2014) Balancing Micro and Macro Practice: A challenge for Social Work. Social Work 59: 91-93.

10. Carey LA (2007) Teaching Macro Practice: An Experiential Learning Project. Journal of Teaching in Social Work 27: 61-71.
11. Argote L, Ingram P, Levine JM, Moreland RL (2000) Knowledge Transfer in Organizations: Learning from the Experience of Others. Organizational Behavior and Human Decision Processes 82(1): 1-8.

12. Donaldson LP, Fogel SJ, Hill K, Erickson C, Ferguson S (2016) Attitudes Toward Advanced Licensing for Macro Social Work Practice. Journal of Community Practice 24(1): 77-93.

13. Corvo K, Selmi P, Montemaro S (2003) Icons of conformity: The Marketing of Social Work Education. Journal of Community Practice 11(1): 85-99. 